\title{
Criminal Law Policy in Law Enforcement of Sim-Swab Crime
}

\author{
Dwi Margono*) and Jawade Hafidz ${ }^{* *}$ \\ *) Police of Republic Indonesia, E-mail: margono.memet@gmail.com \\ ${ }^{* *}$ Faculty of Law, Universitas Islam Sultan Agung Semarang
}

\begin{abstract}
This study aims to examine and analyze criminal law policies in law enforcement of SIMSwab crimes, obstacles and legal consequences as well as solutions in law enforcement of SIM-Swab crimes. The research method and approach method used in solving the problem is empirical juridical, namely by reviewing the applicable legal provisions and what is happening in reality in society. The results showed that emergence and development of SIMSwab crimes has a complex background, not only due to unplanned and well-organized economic development, but also other socio-political factors. Therefore, without being supported by policies in other development fields such as social, economic and political fields, the use of criminal law as a means of overcoming SIM-Swab crimes has very limited capabilities. To optimize the function of criminal law in this effort, it is necessary to integrate social policies and criminal politics as well as integration between the use of penal and nonpenal means. The enforcement of criminal law against SIM-Swab crimes has not been maximized and the crimes continue to grow. This is inseparable from the various obstacles faced. First, related to the characteristics of SIM-Swab crimes that are difficult to detect. Second, theoretically, criminal law juridical itself provides limitations in law enforcement and there are still various problems, both regarding the substance of the law, law enforcers, conflicts of interest in society, supporting facilities and legal culture in the banking community. So it is necessary to have a number of policies to correct the various deficiencies that exist.
\end{abstract}

Keywords: Criminal Law Policy; Law Enforcement; Investigation; SIM-Swab Crime.

\section{Introduction}

Advances in information and communication technology are getting faster so that it affects every aspect of human life, without realizing that technological products have become daily necessities, the use of television, telephone, fax, cellular phones (mobile phones) and the internet is not a strange and new thing, especially in cities. ${ }^{1}$

The development of computer and internet technology which is influenced by the concept of cybernertics has given birth to a new world known as cyberspace, global village, or the internet and marks the start of a new era, namely the digital era or the information age. ${ }^{2}$ Recently, there have been many SIM-swab crimes, namely by making a new SIM (Subscriber Identity Module) card.

Sudikno Mertokusumo in his book distinguishes the method of legal discovery into three, namely the method of interpretation, the method of

\footnotetext{
${ }_{1}^{1}$ Dikdik M Arief Mansur and Elisatris Gultom, 2005, Cyber Law Aspek Hukum Teknologi Informasi, Replika Aditama, Bandung, p. 121.

${ }_{2}^{2}$ Josua Sitompul, 2012, Cyberspace Cybercrime Cyberlaw Tinjauan Aspek Hukum Pidana, PT Tatanusa, Jakarta, p. 31
} 
argumentation, and the method of exposition (legal construction).. ${ }^{3}$ In connection with the obligation of judges to explore, follow and understand legal values and a sense of justice that lives in society, the use of theories of discovery and interpretation of law can be carried out in deciding a case for cases where the law/law is not/not yet clear. However, the use of the theory of discovery and interpretation of law must be carried out by means or methods of interpretation that apply in the science of law. Law enforcement is an effort to realize the ideas and legal concepts that the people expect to become a reality. Law enforcement is a process that involves many things. ${ }^{4}$

Based on the background of thought above, this study aims to determine the policy of criminal law in law enforcement of SIM-Swab crime, and what are the obstacles and legal consequences as well as solutions in law enforcement of SIMSwab crime.

\section{Research Methods}

This research is included in the type of empirical juridical research or called field research, namely examining the applicable legal provisions and what happens in reality in society. ${ }^{5}$ Empirical juridical research is legal research regarding the enforcement or implementation of normative legal provisions in action on every particular legal event that occurs in society. ${ }^{6}$

In this study, the approach used in solving the problem is to use an empirical juridical approach. The juridical approach in question is law as a norm or das sollen), because in discussing the problems in this study, legal materials are used. While the empirical approach is to look at the law as a social, cultural or das sein reality because in this study the data used were obtained directly from the research location.

The secondary data in this study were obtained by means of a literature study. Secondary data as a theoretical basis to base the analysis of the subject matter. Primary legal materials, consisting of the 1945 Constitution, Criminal Code, Criminal Procedure Code and Act No. 11 of 2008 as amended by Act No. 19 of 2016 concerning Amendments to Act No. 11 of 2008 concerning Information and Electronic Transactions, Act No. 36 of 1999 concerning Telecommunications and Act No. 3 of 2011 concerning Fund Transfer. Meanwhile, the secondary legal materials used in this research are books, journals, and documents resulting from research in the field of law, especially those related to banking crimes and SIMSwab. Tertiary legal materials, consisting of Indonesian Language Dictionary, English Dictionary, Law Dictionary and teaching tools (hand out) on procedures for writing scientific papers.

In this study, the types of data collected were divided into two types of data, namely primary data and secondary data. Primary data or data obtained directly from data sources at the research location or field (field research) are obtained

\footnotetext{
3 Sudikno Mertokusumo, 2007, Penemuan Hukum Sebuah Pengantar, Liberty, Yogyakarta, p.56

${ }^{4}$ Dellyana, 1988, Shant, Konsep Penegakan Hukum, Liberty, Yogyakarta, p. 32

${ }^{5}$ Suharsimi Arikunto,2012, Prosedur Penelitiaan Suatu Pendekatan Praktek, Jakarta, Rineka Cipta, p. 126

${ }^{6}$ Abdulkadir Muhammad, 2004, Hukum dan Penelitian Hukum, Bandung, Citra Aditya Bakti, p. 134
} 
through interviews and observations. While secondary data is obtained by reviewing and studying library materials (literature research) in the form of legal materials, both primary secondary and tertiary legal materials.

The data analysis method used is descriptive qualitative. The data analysis method used is qualitative normative. Normative because this research is based on existing regulations as positive legal norms, while qualitative means data analysis that is based on information obtained from respondents to achieve clarity on the problems to be discussed.

\section{Results and Discussion}

\subsection{Criminal law policy in law enforcement of SIM-swab crimes}

In general, people recognize law as a rule, norm, code of ethics or legislation which if violated will be subject to sanctions. The purpose of the establishment of the law is as an order that must be implemented by the community, so as to create a safe, peaceful and peaceful environment, in addition to realizing truth and justice. $^{7}$

In every crime that occurs in society, not all of these crimes can be easily proven or determined who the perpetrators of these crimes are. ${ }^{8}$ Currently, Indonesia does not have laws and regulations that specifically regulate criminal acts related to SIM-swab crimes. The law contains rules that become general guidelines for individuals to behave in society, both in their relationships with other people and in their relationships with society. Rules that set boundaries for the community to burden or otherwise act against the individual. The existence of these rules and regulations creates legal certainty. ${ }^{9}$

In the tradition of the civil law system, there are four aspects of the principle of legality that are strictly applied, namely: written legislation (law), retroactivity (retroactivity), lex certa, and analogy. ${ }^{10}$

- Lex Scripta: written, the criminal law must be in writing.

- Lex Certa: Clear and Detailed, In relation to written law, legislators (legislature) must formulate clearly and in detail the actions that are called criminal acts (crimes).

- Non-retroactive: The principle of legality requires that the provisions of laws and regulations that formulate criminal acts cannot be applied retroactively (retroactive).

\footnotetext{
${ }^{7}$ Zahri Aeniwati \& Sri Kusriyah. Legal Protection from Provocate Abortion Againts the Child Conceived Because Rape (Case Study on Jurisdiction Ex Residency of Cirebon). Law Development Journal. Vol. 3, No. 4 (2021), p. 11 url:http://jurnal.unissula.ac.id/index.php/RH/article/view/8435 8Wilddan Auliya and Jawade Hafidz, Law Enf orcement againstCriminal Action with Fingerprint Evidence, Law Development Journal. p. 304 url: http://jurnal.unissula.ac.id/index.php/ldj/article/download/11929

${ }^{9}$ Suwanto, Sri Kusriyah and Bambang Tri Bawono, March 2020, Criminal Aspects Of The Fiduciary GuaranteeTransferAs Decision Basis On Criminal Justice Process, Jurnal Daulat Hukum, Vol.3 Issue 1, Faculty of Law, Universitas Islam Sultan Agung, Semarang. p. 98. url: http://jurnal.unissula.ac.id/index.php/RH/article/view/8405

10 Moelyatno, Asas-asas Hukum Pidana, seventh printing, Rineaka Cipta, Jakarta 2002, p.355
} 
- Analogy: Analogy means expanding the validity of a regulation by abstracting it into a legal rule that forms the basis of the regulation (ratio legis) and then applying this general rule to concrete actions that are not regulated by law. The application of regulations by analogy is carried out if there is a void in the law for actions (events) that are similar to what is regulated in the law. On the other hand, if there is a new event that is not regulated by law, the regulation will not be applied if it is not in accordance with the ratio of the regulation.

As described above, the principle of legality limits in detail and carefully what actions can be punished. However, in its application the science of law provides an opportunity for interpretation of the formulations of the prohibited acts $^{11}$.

In criminal law, there are several methods or ways of interpretation, namely grammatical or grammatical interpretation, historical interpretation, systematic interpretation, teleological or sociological interpretation, reverse interpretation, limiting interpretation, broadening interpretation and analogy interpretation. ${ }^{12}$

- grammatical interpretation (according to language), i.e. grammatical interpretation means only remembering the sound of the words in the sentence.

- historical interpretation, namely providing an interpretation based on its history, both based on the history of the occurrence of the law and based on the history of the formation of the law.

- systematic interpretation, namely interpretation based on the composition and relationship with the sounds of other articles or interpretation based on whether or not it is in accordance with the legal system.

- teleological or sociological interpretation, namely interpretation keeping in mind the intent and purpose of the law.

- Authentic / official / valid interpretation, namely giving an interpretation as determined by the legislator himself.

- extensive interpretation, namely providing interpretation by expanding the meaning of words in the provisions of the law, so that an event can be included.

- comparative interpretation, interpretation by looking for an explanation based on comparative law so that the provisions of the law become clearer.

- futuristic interpretation, explanation of the provisions of the law by referring to laws that do not yet have legal force.

- Interpretation of analogy, actually analogy is not included in interpretation, because analogy is the same as qiyas, which is to give likeness to the words according to the law, so that an actual event cannot be included, then considered according to the sound of the regulation.

With this interpretation, the policy of criminal law enforcement in the investigation process of the SIM-swab crime takes a policy by applying the rules of criminal law in general, namely as contained in the Criminal Code and using specific laws and regulations, namely Act No. 11 of 2008 concerning Information and Electronic Transactions, Act No. 36 of 1999 concerning Telecommunications and Act No. 3 of 2011 concerning Fund Transfers.

${ }^{11}$ Sri Endah Wahyuningsih, "Model Pengembangan asas hukum pidana dalam KUHP berbasis nilainilai ketuhanan yang Mahan Esa", Semarang, Fastindo, 2018, p. 52

${ }^{12}$ Ibid, Sri Endah Wahyuningsih, p. 53-54 
The policy of criminal law enforcement in the investigation process of the SIM-swab criminal incident uses the following articles:

Article 363 paragraph (1) number $4 \mathrm{e}$ of the Criminal Code:

(1) With a maximum imprisonment of seven years, sentenced:

4e. theft is committed by two or more people together

Article 263 of the Criminal Code:

(1) Any person who makes a forged document or falsifies a letter that can give rise to a right, an agreement or debt relief, or which is intended as evidence of something with the intention of using or ordering another person to use the letter as if the contents are true and not falsified, is threatened if such use may result in loss due to forgery of a letter, with a maximum imprisonment of six years.

(2) Threatened with the same punishment, whoever deliberately uses a forged or falsified document as if it were real, if the use of the letter can cause harm.

Article 32 paragraph (1) of the Act No. 11 of 2008 concerning Information and Electronic Transactions:

(1) Everyone intentionally and without public525u against the law in any way alter, add, reduce, transmit, destroy, delete, transfer, hide an Electronic Information and/or Electronic Documents belonging to other people or belonging to the public.

Article 48 paragraph (1) of the Act No. 11 of 2008 concerning Information and Electronic Transactions:

(1) Everyone who fulfills the elements as referred to in Article 32 paragraph (1) shall be sentenced to a maximum imprisonment of 8 (eight) years and/or a maximum fine of IDR 2,000,000,000.00 (two billion rupiah).

Article 81 of the Act No. 3 of 2011, concerning Transfer of Funds:

"Any person who unlawfully takes or transfers part or all of the funds belonging to another person through a fake funds transfer order"

Article 82 of the Act No. 3 of 2011 concerning Fund Transfer

"Recipients who intentionally receive or accommodate, either for themselves or for others, a Fund which is known or reasonably suspected to have originated from a Funds Transfer Order made unlawfully shall be punished with imprisonment for a maximum of 4 (four) years and/or a fine at most IDR1,000,000,000.00 (one billion rupiah)"

Article 22 Article 50 of the Act No. 36 of 1999 concerning Telecommunications:

"Everyone is prohibited from committing acts without rights, illegal or manipulating:

a. access to telecommunications networks; and or

b. access to telecommunications services; and or

c. access to special telecommunications networks

Article 50 UURI No. 36 of 1999 concerning Telecommunications;

"Whoever violates the provisions as referred to in Article 22, shall be sentenced to a maximum imprisonment of 6 (six) years and or a maximum fine of IDR 600,000,000.00 (six hundred million rupiah)"

\subsection{Obstacles and Legal Consequences and Solutions in Law Enforcement for Sim-Swab Crime}


The main problem of law enforcement actually lies in the factors that may influence it. These factors have a neutral meaning so that the positive or negative impact lies in the content of these factors. These factors are as follows: ${ }^{13}$

- The legal factor itself, for example the law.

- Law enforcement factors, namely the parties that form and apply the law.

- Factors of facilities and activities that support law enforcement.

- Community factors, namely the environment in which the law applies or is applied.

- Cultural factors, namely as a result of work, creativity and taste based on human initiative in social life.

These five factors are closely related, because they are the essence of law enforcement, and are also a measure of the effectiveness of law enforcement. Barriers to law enforcement have resulted in the ineffectiveness of supporting factors in law enforcement. The obstacle lies in the factors, namely:

- Legal Factor

There is no permanent rule that specifically regulates SIM-swab crime so that it takes courage to explore, follow and understand legal values and a sense of justice that lives in society, so the use of theories of discovery and legal interpretation can be carried out in deciding a case for cases where the law/law is not/not yet clear. Besides that, there are also overlapping rules, which become an obstacle in the process of handling criminal acts. The resulting legal consequences are that it takes a relatively long time to review the application of the right legal rules that are applied in handling SIM-swab crime.

- Law Enforcement Factor

Many cases are constrained due to the number of professional law enforcement officers who are able to handle criminal acts in the banking sector SIM-swab crime still very limited. Besides that, it is impossible for us to expect law enforcers to be able to master various very broad and complex aspects relating to various disciplines. Limited knowledge and understanding of law enforcement officers regarding SIM-swab crime become a very dominant constraint factor in efforts to create a common perception of law enforcement officers handling cases, both investigators, public prosecutors and judges who will try. The legal consequence is that there are differences in the direction of the application of laws and regulations. The solution is to increase the knowledge and skills of law enforcement officers and increase coordination between law enforcement officers who handle cases involving SIM-Swab crimes.

- Facility and activity factors

Meansand activities are tools to achieve law enforcement goals. The absence or limitations of facilities and supporting facilities (including funds), will greatly affect the success of law enforcement for the SIM-Swab crime. The handling of the SIM-Swab crime involves a variety of sophisticated technological devices, which to obtain it requires a very expensive fee and its operation requires experts. In addition, confidential data that is protected by law is also needed. The legal consequence is the lack of maximum law enforcement both at the

13 Soerjono Soekanto, 1996, Kejahatan dan Penegakan Hukum di Indonesia, Rineka Cipta, Jakarta, p.8. 
stage of investigation, prosecution and punishment. The solution is to facilitate law enforcement officers with infrastructure and authority in accordance with the interests of law enforcement for the SIM-Swab crime.

- Community Factor

Compliance and adherence to legal provisions is an indicator of public legal awareness. Community participation is the main component, in addition to the existence of law enforcement, to achieve legal goals through law enforcement facilities. One of the obstacles that emerged from the community was the lack of public awareness of the new modus operandi that emerged as a result of the development of technology, including the crime of SIM-Swab. The legal consequence is that SIM-Swab crimes are increasingly widespread. The solution is to socialize and publish the SIM-Swab crime.

- Cultural Factor

The culture of modern society in developing countries is supported by rapid technological advances that encourage a high sense of curiosity so that there is an intention or desire to try something new without thinking that what they do has legal consequences that violate existing laws and regulations or harm other people and society in general. The resulting legal consequences are the increasing number of criminal cases in the field of SIM-Swab crimes while the old cases or other cases have not been handled. The solution is to socialize and publish the SIM-Swab crime.

\section{Closing}

The policy of criminal law enforcement against SIM-swab crimes is to apply general criminal law rules, namely as contained in the Criminal Code, namely Article 363 paragraph (1) number 4e of the Criminal Code on theft, Article 263 of the Criminal Code on counterfeiting and using special laws and regulations, namely Article 48 paragraph (1) article junto article 32 paragraph (1) of the Act No. 11 of 2008 concerning Information and Electronic Transactions, Article 50 junto article 22 of the Act No. 36 of 1999 concerning Telecommunications and article 81 or article 82 of the Act No. 3 of 2011 concerning Fund Transfers. Inhibiting factors in law enforcement against SIM-swab crimes consist of legal factors, Law Enforcement, Facility and activity factors, Community factors and Cultural factors. Not yet criminal regulations discussing SIM-swabs are juridical obstacles that result in differences in the application of regulations by law enforcement officers who interpret existing legislation as a solution. Non-juridical barriers are law enforcement factors who are required to have knowledge and skills result in the improper application of laws and regulations, so law enforcement officers must improve knowledge and skills. Another non-juridical obstacle is the factor of inadequate facilities and infrastructure or activities to support law enforcement resulting in law enforcement to the extent of its ability. The solution is updating law enforcement facilities and infrastructure. Community factors in this case legal awareness and cultural factors in this case curiosity and trying something new that can harm other people or violate the law are one of the obstacles that result in the increasing number of SIM-Swab crimes, so socialization and publication of SIMSwab crime disclosures are needed. 


\section{References}

\section{Journal}

[1] Suwanto, Sri Kusriyah and Bambang Tri Bawono, March 2020, Criminal Aspects of The Fiduciary GuaranteeTransferAs Decision Basis On Criminal Justice Process, Jurnal Daulat Hukum, Vol.3 Issue 1, Faculty of Law, Universitas Islam Sultan Agung, Semarang. p. 98. url: http://jurnal.unissula.ac.id/index.php/RH/article/view/8405

[2] Wilddan Auliya and Jawade Hafidz, Law Enf orcement againstCriminal Action with Fingerprint Evidence, Law Development Journal. p. 304 url: http://jurnal.unissula.ac.id/index.php/ldj/article/download/11929

[3] Zahri Aeniwati \& Sri Kusriyah. Legal Protection from Provocate Abortion Againts the Child Conceived Because Rape (Case Study on Jurisdiction Ex Residency of Cirebon). Law Development Journal. Vol. 3, No. 4 (2021), p. 11 url:http://jurnal.unissula.ac.id/index.php/RH/article/view/8435

\section{Book}

[1] Abdulkadir Muhammad, 2004, Hukum dan Penelitian Hukum, Bandung, Citra Aditya Bakti

[2] Dellyana, 1988, Shant, Konsep Penegakan Hukum, Liberty, Yogyakarta

[3] Dikdik M Arief Mansur and Elisatris Gultom, 2005, Cyber Law Aspek Hukum Teknologi Informasi, Replika Aditama, Bandung

[4] Josua Sitompul, 2012, Cyberspace Cybercrime Cyberlaw Tinjauan Aspek Hukum Pidana, PT Tatanusa, Jakarta

[5] Moelyatno, Asas-asas Hukum Pidana, seventh printing, Rineaka Cipta, Jakarta 2002

[6] Soerjono Soekanto, 1996, Kejahatan dan Penegakan Hukum di Indonesia, Rineka Cipta, Jakarta

[7] Sri Endah Wahyuningsih, 2018, "Model Pengembangan asas hukum pidana dalam KUHP berbasis nilai-nilai ketuhanan yang Mahan Esa", Semarang, Fastindo

[8] Sudikno Mertokusumo, 2007, Penemuan Hukum Sebuah Pengantar, Liberty, Yogyakarta

[9] Suharsimi Arikunto, 2012, Prosedur Penelitiaan Suatu Pendekatan Praktek, Jakarta, Rineka Cipta

\section{Regulation}

[1] Criminal Code

[2] Criminal Procedure Code

[3] Act No. 11 of 2008 concerning Information and Electronic Transactions,

[4] Act No. 36 of 1999 concerning Telecommunications

[5] Act No. 3 of 2011 concerning Fund Transfers

\section{Internet}

[1] https://id.wikipedia.org/wiki/Kartu SIM, (accessed July 02, 2001)

[2] https://www.bbc.com/indonesia/dunia-49534475 (accessed July 02, 2001) 
[3] https://www.ncsl.org/research/financial-services-and-commerce/creditcard-skimming-devices-laws-and-legislation.aspx\#Statutes (accessed June 21, 2021) 